\title{
INNOVATIVE HEAT-TECHNOLOGY OF PROCESSING PHYTOESTROGENIC RAW MATERIALS INTO FUNCTIONAL POWDERS
}

\author{
Petrova Zh.O., Academician UAS, Doctor of Technical Sciences, Chief Researcher, \\ Slobodianiuk K.S., PhD, Junior Researcher \\ Institute of Engineering Thermophysics of NAS Ukraine, Kyiv
}

\begin{abstract}
Outdated technologies in drying processes can lead to irrational use of energy, as a consequence, high energy consumption and increased energy consumption. Therefore, the issues of energy saving and energy efficiency are the most important tasks to be solved. Nowadays, energy saving and energy efficiency are also part of the environmental problem. Ukraine, which has a unique geographical position for Europe, is fully supplied with natural resources, - one of the countries where there is inefficient use of energy resources.

One of the energy-consuming areas of vegetable processing is drying. In the modern world, the issue of energy efficiency of drying methods is one of the most relevant areas of research. Convective drying of vegetable raw materials requires a rational use of regime parameters of the process corresponding to the biochemical properties of the processed object. The primary objectives of this area of processing of vegetable raw materials are to reduce energy costs and ensure high quality characteristics of the final product.

This article presents the developed heat-technology for obtaining phytoestrogenic powder from soybeans and spinach. Which includes 3 stages: preliminary preparation of raw materials for drying; drying of thermolabile vegetable raw materials; dispersion and packaging of the obtained phytoestrogenic powder.

As a result of previously conducted comprehensive research, it was found that the use of heat technology reduces energy costs at the stage of preparation of raw materials through the improvement of existing hydrothermal treatment of soybeans, as well as energy savings of $21 \%$ through the use of developed step modes. Studies of the qualitative characteristics of the obtained phytoestrogenic powder confirm the high quality of the final product.
\end{abstract}

Key words: heat-technology, energy consumption, drying, functional properties, soybeans, spinach.

\section{ІННОВАЦІЙНА ТЕПЛОТЕХНОЛОГІЯ ПЕРЕРОБКИ ФІТОЕСТРОГЕННОЇ СИРОВИНИ НА ФУНКЦІОНАЛЬНІ ПОРОШКИ}

\author{
Петрова Ж.О., Академік УАН, д-р.техн.наук, гол.наук. співр., \\ Слободянюк К.С., канд.техн.наук, м.н.с. \\ Інститут технічної теплофізики НАН України, м. Київ
}

\begin{abstract}
Анотація. Застарілі технологї в процесах сушіння можуть призвести до нераціонального використання енергоносіїв, як наслідок, високих витрат енергї та приріст споживання енергоресурсів. Отже, питання енергозбереження та енергоефективність ие найважливімі завдання для вирішення. В наш час енергозбереження та енергоефективність цее також частина проблеми екології. Украӥна, має унікальне для Свропи географічне положення, повністю забезпечена природними ресурсами, - одна з краӥн, де відбувається неефективне використання енергоресурсів.

Одним із енерговитратних напрямків переробки рослинної сировини є сушіння. В сучасному світі питання енергоефективності способів сушіння - одне з найактуальніших напрямків досліджень. Конвективне сушіння рослинної сировини вимагає раціонально обгрунтованого застосування режимних параметрів процесу, відповідних до біохімічних властивостей об'єкту переробки. Першочерговими завданнями зазначеного напрямку переробки рослинної сировини є зменшення енергетичних витрат та забезпечення високих показників якісних характеристик кінцевого продукту.

В даній статті представлено розроблену теплотехнологію отримання фітоестрогенного порошку із сої та шпинату. Яка включає 3 етапи: попередню підготовку сировини до сушіння; сушіння термолабільної рослинної сировини; диспергування та фасування отриманого фітоестрогенного порошку.

В результаті попередньо проведених комплексних досліджень, встановлено щзо використанням теплотехнології досягається зменшення енергетичних витрат на етапі підготовки сировини через удосконалення існуючої гідротермічної обробки соєвих бобів, також економія енергоносїв $21 \%$ за рахунок використання
\end{abstract}


розроблених ступеневих режимів. Дослідженнями якісних характеристик отриманого фітоестрогенного порошку підтверджується висока якість кінцевого продукту.

Ключові слова: теплотехнологія, енерговитрати, сушіння, функціональні властивості, соя, шпинат.

With the development of scientifically sound concepts of recipes in food production, as well as the demand for diversity in food products, there is a tendency to expand the market of food ingredients. Most of the ingredients come in powder form and because of this the technology is extremely important. The two main aspects are that plant powders are of biological origin and they are consumed by humans for food. The main reason for the processing of vegetable raw materials is the extension of the shelf life due to dehydration and maximum preservation of all biologically active substances. It is proved that the stability and functional properties of vegetable raw materials before its use are maintained in the form of powder (Fitzpatrick and Lilia, 2005) [1].

Soybeans are rapidly gaining popularity in the diet of people worldwide. Soy-based protein products are a perfectly balanced source of essential amino acids, which is a supplement to cereal proteins and can completely replace animal protein. There are more than 50 types of processed soy products [2]. Particularly common are: soy protein concentrate; soy isolate; meat and dairy substitutes; tofu (soy cheese).

Functional properties of soybean products are important components for: baking, food concentrate, confectionery and pasta industries (table 1). Consumption of products of these industries with the use of soy products prevents obesity, metabolic disorders due to low calorie and nutritional value of soy foods. The addition of phytoestrogenic powder can improve the structural properties of the dough.

Functional properties of soy products [2]

Table 1

\begin{tabular}{|c|c|c|c|}
\hline $\begin{array}{l}\text { Functional proper- } \\
\text { ty }\end{array}$ & Mode of action & $\begin{array}{l}\text { Types of products in which it is } \\
\text { used }\end{array}$ & Soy product \\
\hline Solubility & $\begin{array}{l}\text { Dissolution of proteins, } \\
\text { depends on } \mathrm{pH}\end{array}$ & Beverage concentrates & $\begin{array}{l}\text { Flour, concentrate, } \\
\text { isolate, soy milk }\end{array}$ \\
\hline $\begin{array}{l}\text { Water absorption } \\
\text { and binding }\end{array}$ & $\begin{array}{l}\text { Binding of water by hy- } \\
\text { drogen, capture of water }\end{array}$ & $\begin{array}{l}\text { Bakery products, cakes, fon- } \\
\text { dant, flour confectionery }\end{array}$ & $\begin{array}{l}\text { Flour, concentrate, } \\
\text { texture, tofu }\end{array}$ \\
\hline Viscosity & Thickening, water binding & $\begin{array}{l}\text { Concentrates of soups, sauces, } \\
\text { ready fillings for buttery bakery } \\
\text { and flour confectionery }\end{array}$ & $\begin{array}{l}\text { Flour, concentrate, } \\
\text { isolate }\end{array}$ \\
\hline Gelation & $\begin{array}{l}\text { Formation of protein ma- } \\
\text { trix, hardening }\end{array}$ & $\begin{array}{l}\text { Lozenges-marmalades, mouss- } \\
\text { es, creams }\end{array}$ & Concentrate, isolate \\
\hline Stickiness, sticking & $\begin{array}{l}\text { A protein that acts as a } \\
\text { binding material }\end{array}$ & Pasta & $\begin{array}{l}\text { Flour, concentrate, } \\
\text { isolate }\end{array}$ \\
\hline Elasticity & $\begin{array}{l}\text { Disulfide bonds in de- } \\
\text { formable gels }\end{array}$ & Baked goods & Flour, isolate \\
\hline Emulsification & $\begin{array}{l}\text { Formation and stabiliza- } \\
\text { tion of fat emulsions }\end{array}$ & $\begin{array}{l}\text { Food concentrates for lunch, } \\
\text { cakes, fillings and decorations } \\
\text { for confectionery }\end{array}$ & concentrate, \\
\hline Fat absorption & Binding of free fats & $\begin{array}{l}\text { Donuts, confectionery masses: } \\
\text { praline, jelly, cream }\end{array}$ & $\begin{array}{l}\text { Flour, concentrate, } \\
\text { isolate, texture, tofu }\end{array}$ \\
\hline $\begin{array}{l}\text { Binding of flavor- } \\
\text { ing substances }\end{array}$ & $\begin{array}{l}\text { Absorption, capture, selec- } \\
\text { tion }\end{array}$ & $\begin{array}{l}\text { Food concentrates of lunch } \\
\text { dishes, desserts, bakery products }\end{array}$ & $\begin{array}{l}\text { Flour, concentrate, } \\
\text { isolate, texture, tofu }\end{array}$ \\
\hline Foaming & $\begin{array}{l}\text { Formation of a film to } \\
\text { capture gas }\end{array}$ & $\begin{array}{l}\text { Whipped creams, desserts, muf- } \\
\text { fins from whipped protein }\end{array}$ & isolate \\
\hline Color control & Bleaching (lipoxygenase) & Bakery products & Flour, tofu \\
\hline
\end{tabular}

By following the correct modes of technology for the production of phytoestrogenic powder from soybeans and spinach, you can get a valuable product with functional properties, which is able to enrich the products of processing of the baking, food concentrate, dairy, confectionery and pasta industries [3].

In the basis of a healthy diet, vitamin saturation and dietary nature remains the leader and is becoming increasingly popular the spinach. Spinach does not have a pronounced taste due to its natural properties. There are a huge number of recipes for dishes that include spinach.

The shelf life of vegetables mainly depends on the type. For example, leafy vegetables (spinach) have a limited shelf life, but root vegetables reach a shelf life of many months. Variations in the combination of root, legume and leaf in the mixture can be the basis for extending the shelf life of the dried product. Therefore, there are technologies for combining vegetable raw materials in the mixture. 


\title{
Одеська національна академія харчових технологій ТЕОРЕТИЧНІ ТА ЕКСПЕРИМЕНТАЛЬНІ ДОСЛІДЖЕННЯ ГІДРАВЛІЧНИХ, ТЕПЛОВИХ ТА МАСООБМІННИХ ПРОЦЕСІВ
}

\begin{abstract}
Analysis of recent research. Analysis of the state of protein deficiency, the dynamics of cultivation and the impact on human health and longevity of soybeans showed a positive trend of increasing demand for soybeans and soybean products [4]. High energy consumption at enterprises where drying processes are implemented (energy consumption per process $10-12 \%$ of total energy consumption), all the above causes insufficient development of heat-technologies for processing protein-containing vegetable raw materials, resulting in a product with a short shelf life, degraded organoleptic characteristics, color and taste, and are the root causes for the development of energyefficient heat technologies.

The technology of drying protein-containing raw materials (soybeans) and the quality of the obtained product largely depend on its properties and chemical composition. Soybean as an object of drying is characterized by a number of features due to its biological nature, which must be taken into account when choosing the type of drying equipment and conditions of the dehydration process [5], namely: high initial moisture content; thermolability (color, aroma, taste, structure, nutritional value of the product deteriorate, proteins are denatured when using high coolant temperatures); content of anti-food components (trypsin inhibitor) that require additional energy consumption for inactivation; high amount of lipids (fats), which reduces the shelf life of finished products. From previous studies it is known that the most influential on the quality of the obtained powders is the temperature and stabilization of biologically active substances [5].

Setting objectives. Soybeans contain a high $\%$ of fat, so during its processing and storage it is necessary to provide conditions that prevent oxidation. For this purpose soy was blended with vegetable raw materials which in the structure contain natural stabilizers of lipids [6].

The main research material. Based on research [7], heat-technology for obtaining phytoestrogenic powder from soybeans and spinach was developed $[8,9]$. Soybeans in the crushed state without the addition of spinach in a short time are oxidized and are not saved longer than 3 months without stabilizers of unnatural origin [3]. The technological scheme of obtaining phytoestrogenic powder is presented in Fig. 1.
\end{abstract}

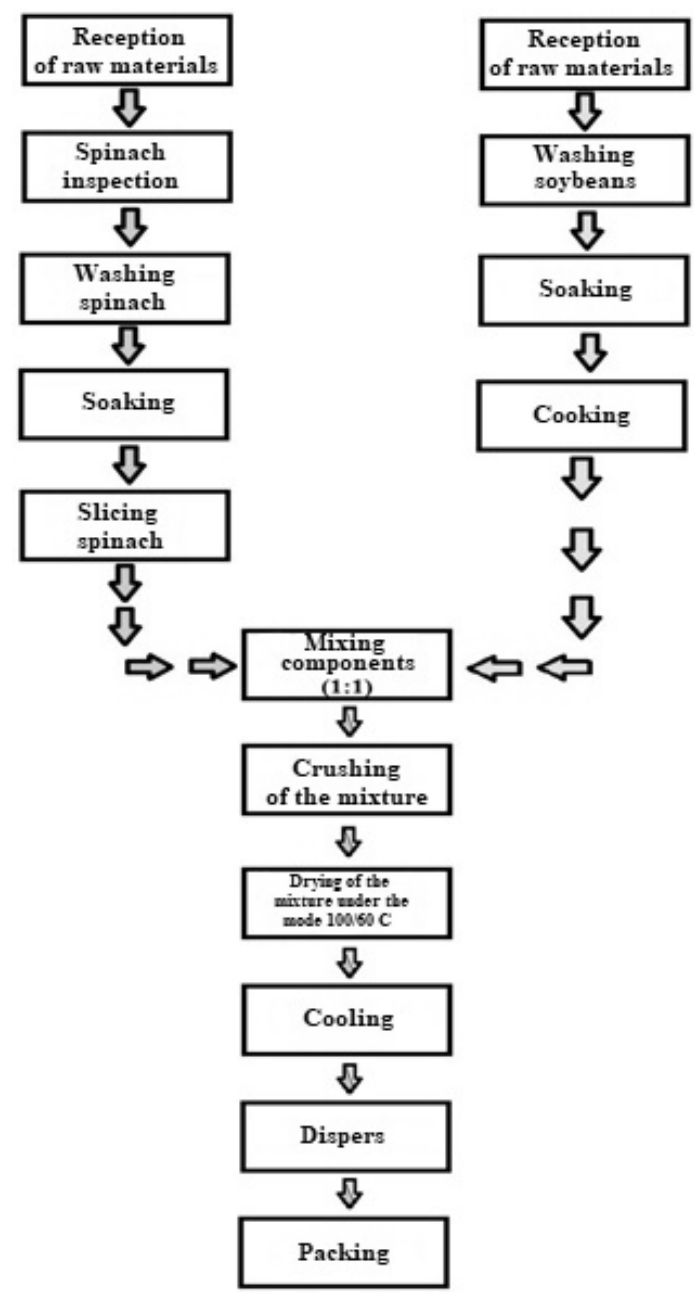

Fig. 1 - Technological scheme of obtaining phytoestrogenic powder from soybeans and spinach [7] 


\section{Одеська національна академія харчових технологій ТЕОРЕТИЧНІ ТА ЕКСПЕРИМЕНТАЛЬНІ ДОСЛІДЖЕННЯ ГІДРАВЛІЧНИХ, ТЕПЛОВИХ ТА МАСООБМІННИХ ПРОЦЕСІВ}

The most important technological stage is the preliminary preparation of raw materials. At the beginning, whole soybeans enter the bean washing machine through the receiving hopper. Then soybeans are soaked in water $\left(50{ }^{\circ} \mathrm{C}\right)$ for 1 hour. At this stage, the oligosaccharides are removed. After soaking, soybeans are boiled at a temperature of $100^{\circ} \mathrm{C}$ for 20 minutes (to inactivate anti-food components). After that, the hot soybeans are fed to the stage of mixing and grinding the components.

Spinach is inspected and served for washing and soaking. The duration of soaking is 15-20 minutes. After that, the raw material is sent for slicing, then inspected, if necessary, cut by hand to a given size, and dosed to the stage of mixing with soybeans and subsequent grinding of the mixture in a ratio of $1: 1$.

The obtained crushed mixture of soybeans and spinach is unloaded on the pallets of trolleys of a two-zone drying unit, where a two-stage drying process is implemented $100 / 60{ }^{\circ} \mathrm{C}$, dried to final humidity $4-8 \%$ and cooled at 20 ${ }^{\circ} \mathrm{C}$.

The dried mixture is dispersed on a hammer mill and fed to the semi-automatic packing machine, where it is packaged in kraft-bags.

In order to implement the method of production of phytoestrogenic powder from soybeans and spinach, a production line (Fig. 2) and a list of technological equipment of mainly Ukrainian production are proposed: IET of NAS of Ukraine; Production Enterprise "Technologist", Kharkiv; The company "Химснабжение", Kharkiv; The company "Мідас-A", Kherson; as well as 1 position of Polish production the company «Żarnowski», Gostyń [8]. The production line consists of 3 technological sections: areas of preliminary hydro-thermal preparation (PHTP) of soybeans, pre-cooking (PC) spinach, as well as areas of mixing, grinding the mixture with a ratio of components 1:1, drying and cooling, dispersing and packaging of the finished product.

At the beginning, whole soybeans are fed into the receiving hopper of the inspection conveyor (1), are inspected and get into the washing drum of the bean washing machine (6). Then the soybeans enter the belt blancher (7) (water temperature $60-70^{\circ} \mathrm{C}$ ) for 1 hour. At this stage, the oligosaccharides are removed. After thermostating, soybeans are dosed into the food-cooking boiler KE-400 E (8), where cooked at room temperature $100^{\circ} \mathrm{C}$ for 20 minutes (for inactivation of anti-food components). After boiling, hot beans with a bucket conveyor (5) with the dosing function are fed to the mixer-grinder (9) of the components [8].

In parallel with soybeans, spinach enters the inspection conveyor (1) and fed to the washing and soaking machine (2). The duration of soaking is 15-20 minutes. After that it arrives on the conveyor belt with a knife (3) for cutting, followed by an inspection conveyor (4), where, if necessary, manually cut to size, bucket conveyor (5) with the dosing function is loaded into the machine for mixing-grinding (9) [8].

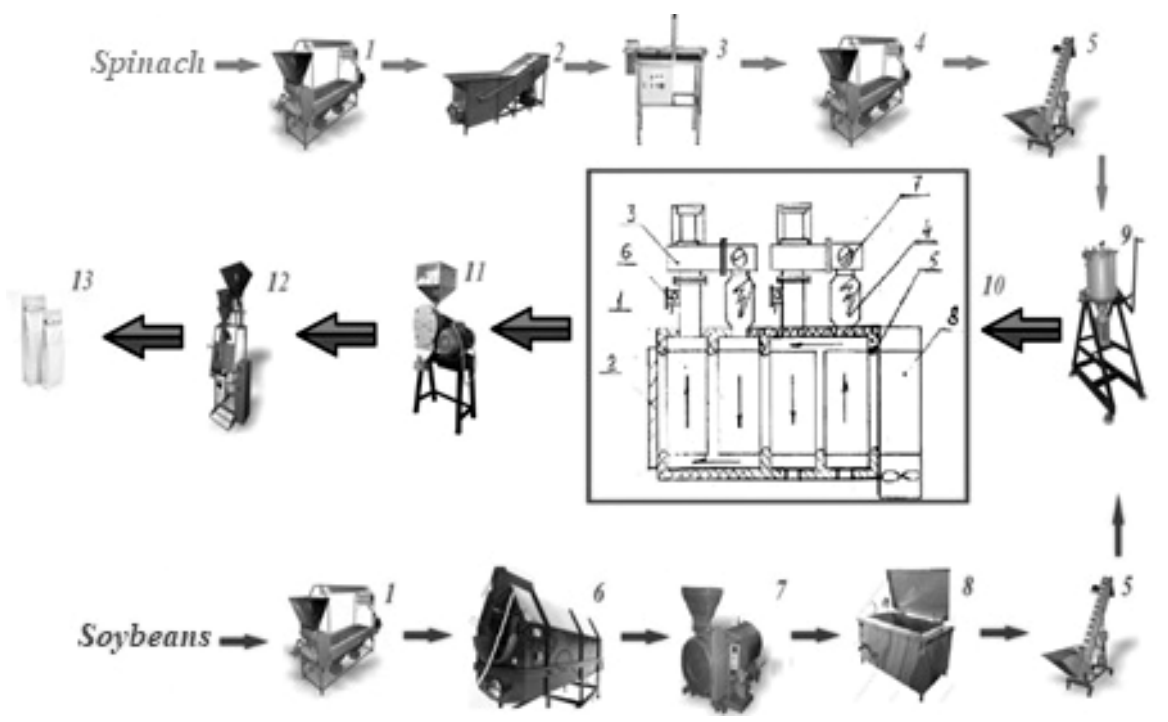

1,4 - inspection conveyor, 2 - the washing machine is unified KUM-3, 3 - conveyor belt with a knife, 5 - bucket conveyor, 6 -drum-type washing machine for washing fruits and vegetables, 7 -tape blancher, 8 - food boiler KE400 E, 9 -mixer-grinder, 10 - the dryer is two-zone on the heat generator TF 2.02, 11 - hammer mill, 12 - packing semiautomatic device, 13 - kraft-packages.

Fig. 2 - Technological line for the production of phytoestrogenic powder from soybeans and spinach [7]

The obtained crushed mixture of soybeans and spinach $(1: 1)$ is unloaded on the pallets of trolleys of two-zone drying unit on heat generator TF 2.02 (10), developed at the Institute of Engineering Thermophysics of NAS of Ukraine, the principle of working and detailed description of which is given in $[10,11]$. implemented two-stage drying process $100 / 60^{\circ} \mathrm{C}$, dried to a final humidity of $4-8 \%$ and cooled at $20^{\circ} \mathrm{C}$.

Наукові праці, Том 84, випуск 1

Scientific Works, Volume 84, Issue 1 
Одеська національна академія харчових технологій

ТЕОРЕТИЧНІ ТА ЕКСПЕРИМЕНТАЛЬНІ ДОСЛІДЖЕННЯ ГІДРАВЛІЧНИХ, ТЕПЛОВИХ ТА МАСООБМІННИХ ПРОЦЕСІВ

The dried mixture is dispersed in a hammer mill (11) and is fed to the packing semiautomatic device (12), where it is packaged in kraft bags (13).

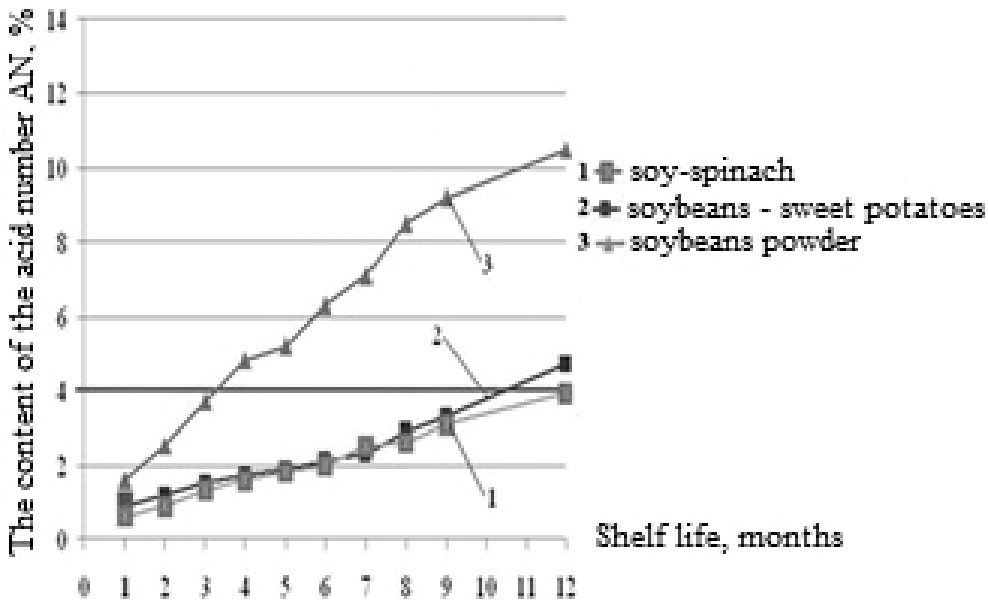

Fig. 3 - Change in acid number during storage of phytoestrogenic raw materials [7]

The study of the qualitative characteristics of the composite powder from soybeans and spinach, as well as from soybeans and sweet potatoes obtained by heat-technology, established an extended shelf life of phytoestrogenic mixtures based on soybeans. When storing soybean mono-powder after three months, the acid number approaches a critical value (4\%), while soybean powder with carotene-containing raw materials is stored for 9-10 months (fig. 3) [8].

Folates and spinach carotenoids stabilize soybean lipids, as a result of this combination, the dried composite phytoestrogenic powder can be stored for up to 10-12 months [8].

A wide range of applications of soy and soy products in various sectors of the pharmaceutical, food and dairy industries indicates the importance of the positive effects of phytoestrogens on the human body (fig. 4) $[8,12]$.

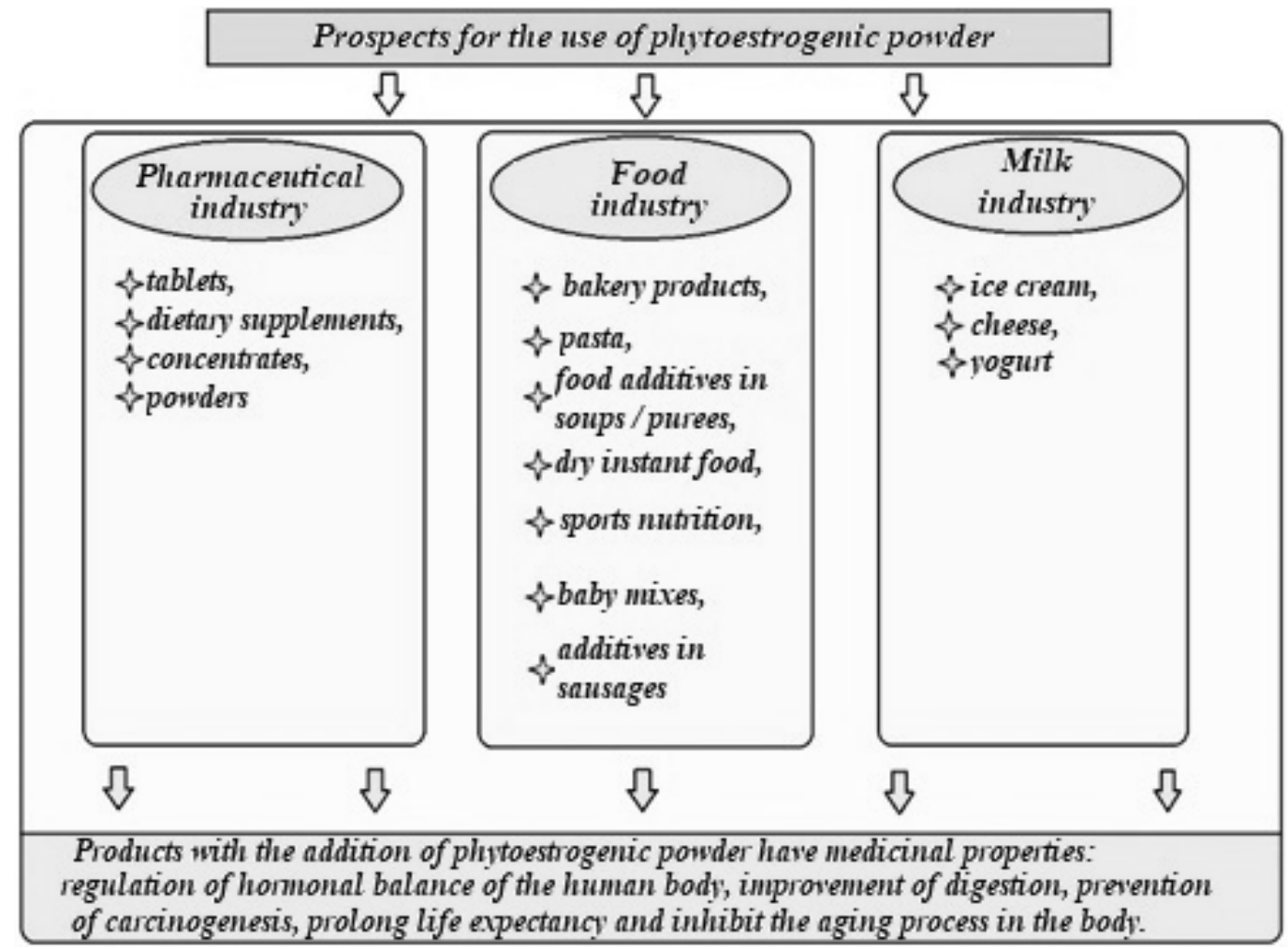

Fig. 4 - The main promising areas of application of phytoestrogenic powder [7] 


\section{Одеська національна академія харчових технологій ТЕОРЕТИЧНІ ТА ЕКСПЕРИМЕНТАЛЬНІ ДОСЛІДЖЕННЯ ГІДРАВЛІЧНИХ, ТЕПЛОВИХ ТА МАСООБМІННИХ ПРОЦЕСІВ}

Conclusions. Creation of vegetable composite mixtures allows to reduce the amount of energy consumption for preparation of raw materials for drying within 20-25\% (innovativeness of preliminary preparation and composite mixtures is confirmed by Patents of Ukraine for invention); the use of step-by-step modes reduces the energy consumption of the drying process within 30-49\%; compliance with all technological regimes provided for in the proposed thermal technology, makes it possible to extend the shelf life of powders in 2 times.

\section{References}

1. John J.Fitzpatrick, LiliaAhrné (2005). Food powder handling and processing: Industry problems, knowledge barriers and research opportunities. Chemical Engineering and Processing: Process Intensification, 44(2), 209214.

2. Drobot, W.B. (2001). Current state and prospects of using soybean products in the baking, pasta, confectionery and food concentrate industries. Scientific works, 21, $295-298$.

3. Petrova, Zh.O., Sniezhkin, Yu.F., Slobodianiuk, K.S., \& Perepelychnyi, O.V.(2017). Patent Ukrainy na vynakhid 115741. Kyiv: Derzhavna sluzhba intelektualnoi vlasnosti Ukrainy.

4. ShawWatanabe, MariUehara (2019). Health Effects and Safety of Soy and Isoflavones. The Role of Functional Food Security in Global Health, Chapter 22, 379-394.

5. Sniezhkin, Yu.F., Petrova, Zh.O., \& Slobodianiuk, K.S. (2017). Rozrobka enerhoefektyvnoi teplotekhnolohii vyrobnytstva fitoestrohennykh poroshkiv. Problemy enerhoefektyvnosti ta yakosti v protsesakh sushinnia kharchovoi syrovyny: tezy dopovidei vseukrainskoi naukovo-praktychnoi konferentsii, prysviachenoi 50richchiu zasnuvannia KhDUKhT, Kharkiv: KhDUKhT.

6. Simoroz, D.O, Stepaniuk, A.R., \& Petrova, Zh.O. (2012). Patent Ukrainy na korysnu model 72165. Kyiv: Derzhavna sluzhba intelektualnoi vlasnosti Ukrainy.

7. Petrova, Zh.O., \& Slobodianiuk, K.S. (2019). Rozrobka enerhoefektyvnoho rezhymu sushinnia fitoestrohennoi roslynnoi syrovyny. Scientific works, 83(1), 85-91.

8. Slobodianiuk, K.S.(2020). Intensyfikatsiia protsesu sushinnia fitoestrohennoi syrovyny na osnovi soi. (Dys. kand. tekhn. nauk). Instytut tekhnichnoi teplofizyky NAN Ukrainy, Kyiv.

9. Petrova, Zh.O., \& Slobodianiuk, K.S. (2017). Energy-saving technology of production of phytoestrogenic vegetable powders. Innovative energy technologies: Abstracts VI International scientific-practical conference, Odessa.

10. Petrova, Zh.O. (2013). Stvorennia enerhoefektyvnykh teplotekhnolohii vyrobnytstva funktsionalnykh kharchovykh poroshkiv. (Dys. dokt. tekhn. nauk) Instytut tekhnichnoi teplofizyky NAN Ukrainy, Kyiv.

11. Snezhkyn, Yu.F., Boriak, L.A., \& Khavyn, O.O. (2004). Enerhosberehaiushchye teplotekhnolohyy proyzvodstva pyshchevikh poroshkov yz vtorychnykh syrevykh resursov. Kyev: Naukova dumka.

12. Petrova, Zh.O. (2017). Tekhnichni umovy «Poroshky fitoestrohenni iz roslynnoi syrovyny». Zmina № 1 TU U 10.3-05417118-047:2012.

Отримано в редакцію 16.06.2020

Прийнято до друку 22.10.2020
Received 16.06.2020

Approved 22.10.2020 